\title{
Legal Origins, Corporate Governance and Environmental Outcomes
}

\section{INTRODUCTION}

Environmental management and corporate sustainability are emerging as some of the central themes of public concern and academic research (Henriques and Sadorsky, 1999; Porter and van der Linde, 1995; Buzzelli, 1991; Greeno and Robinson, 1992; Newman and Breeden, 1992), with the latter leading to an accumulating body of insights into the link between environmental outcomes and various firm level issues. Prior studies have, for instance, looked at the relation between environmental management and performance (e.g., Russo and Fouts, 1997; King and Lenox, 2002), and the contingencies under which managers or firms are more or less likely to reduce their impact on the environment (e.g., King and Lenox, 2002, Aragón-Correa et al., 2004). One recently emerging area of this

environmental management perspective is the focus on corporate governance mechanisms and their effect on environmental performance. Within this 'environmental governance' perspective, Kock, Santaló and Diestre (2012), for instance, show that a variety of 'good' governance mechanisms lead to lower pollution levels, while Berrone et al. (2010) find that specific types of shareholders like families similarly have a positive effect on pollution reduction.

However, while these and other work on environmental governance (see review in Walls et al., 2012) have derived valuable insights into the effects of a wide variety of corporate governance mechanisms on environmental outcomes, they have not considered the underlying origins of these governance structures. In particular, based on the works of La Porta et al. (1997, 1998, 2000, 2002), a number of scholars have documented a 
seemingly pervasive effect of the 'origins of law' on a variety of institutions, such as industrial-relations, securities or corporation law, that govern how firms, investors, labour and other groups behaviour. Recent studies have, for instance, illustrated the role of country-level governance in corporate strategic decisions such as the development of new technologies (Hiller et al., 2011) and foreign investment (Luo et al., 2009). In this origin of law perspective, the primary distinction is made between countries following an Anglo-Saxon case-based 'common law' versus those that apply a version of code-based 'civil law'. Our study extends this perspective to the field of environmental governance.

The work of La Porta et al. has, in fact, been criticized for a lack of focus on such social outcomes. Collison et al. (2012: 394), for instance, diagnose a "narrow ethical perspective" for the legal origins perspective and contend that it essentially prescribes the market based common law system as superior for economic development, leading to "the marginalisation of a stakeholder orientated approach to corporate governance which tends to be identified with practice in civil law countries." Like Collison et al. (2012), who show that measures of societal well-being are enhanced in civil law countries, we also seek to add a 'social dimension' to La Porta et al.'s domain which intrinsically focuses on economic outcomes. We are particularly interested in what the existence of these two legal systems implies for differences in environmental performance, given the previously documented strong influence on the prevailing institutional logics (Herremans, Herschovis, and Bertels, 2009, Collison et al., 2012) and corporate governance systems at country level (e.g., Daniel, Cieslewicz and Pourjalali, 2012). We suggest that this fills a gap in prior work in environmental governance that has assumed a direct link between governance structures and environmental outcomes without considering the possibility that equal governance structures may lead to rather different outcomes depending on the 
institutional logics that influence the decisions of managers, shareholders and other stakeholders.

We argue that the origin of the legal foundations, and the fundamental philosophical orientations associated with these 'origins', will shape the institutional logic of how private property is regarded and treated in a given country. Following Thornton and Ocasio (1999: 804; Friedland and Alford, 1991) we define institutional logics as "the socially constructed, historical pattern of material practices, assumptions, values, beliefs, and rules by which individuals produce and reproduce their material subsistence, organize time and space, and provide meaning to their social reality" which "guide and constrain decision makers in accomplishing the organization's tasks." In fact, prior theorizing and evidence (e.g., Collison et al., 2012) suggests, on one hand, a near perfect alignment between common law and a shareholder primacy view that regards property as the sole prerogative of its owners. Civil law, on the other hand, appears to be strongly aligned with common definitions of a stakeholder orientation, because in this law tradition "property and social responsibility are seen as two sides of the same coin" (La Porta et al, 2008: 309). These shareholder vs. stakeholder focused logics, furthermore, should have a strong shaping influence on the development of corporate governance mechanisms in common vs. civil law countries, which, given the prior findings on environmental governance, should in turn affect firms' environmental performance.

We test our model with country level data on carbon dioxide $\left(\mathrm{CO}_{2}\right)$ emissions. Since the latter account for approximately $80 \%$ of total greenhouse gas emissions (when expressed in $\mathrm{CO}_{2}$ equivalents, Nordhaus, 1991), and are the focus of at least two major international agreements (the 1992 Earth Summit and the 1997 Kyoto Protocol, e.g., Janicke, 2006; Byrne and Glover, 2002) we address with this measure a very important 
and, at the same time, high profile element of worldwide pollution. Our findings show that the origins of law indeed have a strong effect on $\mathrm{CO}_{2}$ emissions, both, via the mediation through the shaping of governance mechanisms as well as directly by influencing the overall institutional logics that govern human behavior.

In addition to this primary shaping effect of legal origins and resulting institutional logics on environmental performance we are also interested in the potential evolution of these effects. Thornton and Ocasio (1999: 802), for instance, called institutional logics "historically variant" and see them as "shaped by economic and social structural changes", and some authors suggest that competing logics may co-exist in the same organizational field (e.g., Lounsbury, 2007; Herremans et al., 2009). Accordingly, we are also curious as to the effects on environmental performance if a predominantly shareholder or stakeholder focused logic in a certain country changes or is challenged by a competing logic. Our specific focus is on the aforementioned international environmental agreements that, we argue, are representative of a stakeholder centric logic of mandating economic actors to care for the environment. If such agreements are entered into by a common law country we would expect new regulatory activity or simply a novel emphasis on 'the environment' to challenge the status quo of the shareholder centric logic and, on the margin - and most likely against resistance - prompt a shift in the direction of a stakeholder logic. Since such a shift is likely to be more pronounced in a common law country than in an already more stakeholder logic focused civil law society we would actually expect the impact of international agreements to be stronger in the common law country. Our empirical findings indeed show that while the direct effect of international agreements - in line with much lamentation about the failure of the 
Kyoto Protocol and other accords (e.g., Purvis, 2004; Fisher et al., 2004) - is not significant on average, common law countries do show a highly significant positive environmental effect in response to these agreements.

We submit that our theoretical model and empirical findings contribute to our understanding of corporate governance and institutional theory as well as more specifically environmental governance by explaining and documenting the strong underlying influence of external legal origins and the associated institutional logics. Our work furthermore suggests a reassessment of the role international agreements play in the quest for environmental protection.

\section{Background: Environmental Governance}

Recent work on environmental governance has highlighted a number of significant interactions between corporate governance mechanisms and environmental performance at the firm level. Kock et al. (2012), in particular, have demonstrated that what is generally considered to be 'good' governance - for instance a board dominated by independent outside directors, or the absence of anti-takeover provisions in corporate charters - is associated with a better environmental performance as measured by US environmental protection agency (EPA) pollution data. Building on the stakeholderagency paradigm developed by Hill and Jones (1992) who suggest that managers can be seen as the agents of various stakeholders, Kock et al. argue that this result obtains because both, shareholders and other stakeholders prefer higher environmental firm efforts than managers since the latter stand to partake only in a fraction of the benefits but have to bear all the effort of implementing difficult environmental strategies. A 'good' governance then allows shareholders - and to an extent also other stakeholders - to 
change the payoff function of managers to favor more environmentally friendly policies.

Similarly, Berrone et al. (2010) used an institutional lens to explain that 'family firms' protect their 'socio-emotional wealth' by catering to external institutional pressures for better environmental performance. Like Johnson and Greening (1999) in the broader context of corporate social performance (CSP), Berrone et al. have suggested a moderating effect of ownership on environmental or social performance. Recently, however, a review by Walls et al. (2012) of select current articles on environmental governance found more mixed results for the link between governance and environmental performance. The summary of prior work in the latter article also suggests that most prior work has utilized a rather simple underlying theoretical model of a direct link between corporate governance mechanisms (e.g., board or compensation structure) and environmental outcomes, often accompanied by moderating effects such as ownership.

In the current paper, we argue that a more comprehensive model is required to integrate these various and partially contradictory findings. Specifically, we suggest that, for instance, institutional effects that may stem from ownership or other sources as suggested by Berrone et al. (2010), themselves are very much rooted in a particular local context, and that our understanding of the governance-environment link is incomplete without an explicit consideration of the underlying institutional logics that at the country level govern both, the structure of corporate governance or ownership of property, and the basic understanding that actors have of these structures and their own roles. To that end we propose to extend the current model of environmental governance by infusing it with ideas developed in the literatures on legal origins (e.g., La Porta et al., 1998, 2002) and institutional logics (Friedland and Alford 1991, Thornton and Ocasio, 1999, 2008). 


\section{Theory and Hypotheses}

La Porta et al. (1997, 1998, 2000, 2002, 2008) suggested that two basic legal traditions are formative of the law systems of most countries in the world - in turn, these 'origins of law' affect a variety of institutions in a given country such as industrial-relation or company law, judicial independence etc., which then shape outcomes such as unemployment rates, stock market development or firm valuations (2008: 292) as well as corporate governance practices (Daniel et al., 2012). These legal origins are, on one hand, Anglo-Saxon style common law that relies on a low degree of codification and a style of dispute resolution that tends to be adversarial rather than inquisitorial, and, on the other hand, a variety of civil law systems that rely on strong codification of law and trace back to ancient Roman law, as well as French, German or Scandinavian law traditions (in the following collectively referred to as 'civil law'). Importantly, these two legal origins have developed from and reflect rather different underlying philosophies and concepts of freedom as La Porta et al. (2008: 303) express with a quote from Hayek (1960: 56): "[Hayek] distinguishes two views of freedom directly traceable to the predominance of an essentially empiricist view of the world in England and a rationalist approach in France: 'One finds the essence of freedom in spontaneity and the absence of coercion, the other believes it to be realized only in the pursuit and attainment of an absolute social purpose." ' In other words, the English common law derives from a search for freedom, which corresponds to historical explanations that see common law developing as a reaction of an emerging economic class against the power of landed gentry and crown in the UK - that is, an attempt to liberate and create security for, and through, private property (La Porta et al., 2008). Law, in this context, can be seen as an approach to arbitrate problems, rather than administer civil action. The latter approach is more reflective of the traditional civil law systems that consider property not so much as 
the sole prerogative of its owner but as having a social component as well. As La Porta et al. (2008: 300) state: "in civil law countries, unlike in common law ones, freedom of contract is counterbalanced by the exercise of public power for the protection of workers in the French tradition, and the communitarian conception of the enterprise in the German one," while in common law settings "contractual freedom is unencumbered by social conditionality."

From this discussion a relatively clear distinction emerges that corresponds to common definitions of a shareholder primacy view (Milton Friedman, 1970: "The social responsibility of business is to increase its profits") for common law, and a stakeholder orientation that sees a responsibility of property for a variety of groups other than shareholders (Freeman, 1984, 1999; Collins et al. 2012). Thus, there appears to be a very strong link between different legal origins and the institutionalized beliefs or 'logics' of ownership (e.g., DiMaggio and Powell, 1983; Meyer and Rowan, 1977, Thornton and Ocasio, 1999; Friedland and Alford, 1991; Scott, 1995) that either property is a sacrosanct expression of freedom and that property owners therefore should have sole discretion over the same, or that property stands in a social responsibility and that therefore the interests of various stakeholders have a legitimate claim over it.

Illustrating this difference in shareholder vs. stakeholder logics, Soshimori (1995), reports survey results indicating that around $74 \%$ of respondents in common law countries (US, UK) perceived their firms as owned by shareholders whereas in civil law countries (Japan, Germany, France) 86\% saw firms as owned by multiple stakeholders.

A reasonable assumption that resonates with recent findings by Daniel et al. (2012) is that these different logics are then reflected in the system of corporate governance as it develops in a certain context. For example, a common law focus on the protection of private property should be reflected in strong minority shareholder protection and rules 
that assure shareholders of primary control of their organizations. In fact, La Porta et al. (2008: 294) argue that "civil law is generally associated with lower shareholder and creditor protection, less efficient debt enforcement, and higher government ownership of banks.” Accordingly, as a baseline hypothesis in accordance with prior research we suggest:

Hypothesis 1: Common Law legal origins will be associated with a corporate governance system that emphasizes shareholder protection.

Combining this baseline from the legal origins literature with the logic of prior work on environmental governance, these socially shaped governance structures should, in turn, affect environmental performance. This happens as the demands of shareholders and stakeholders on individual firms are filtered by the available governance structures. Specifically, reformulating Kock et al.'s (2012) argument presented above by taking managers out of the equation and focusing exclusively on the tension between shareholders and stakeholders, we find it reasonable to assume that the latter have a higher preference for environmental performance than shareholders (e.g., Henriques and Sadorsky, 1999; Sharma and Henriques, 2005). Both groups benefit from environmental protection, but only shareholders also gain directly from the financial performance of a firm - and have to pay for environmental efforts. Thus, the two groups will be in synch as long as environmental performance also leads to good financial performance - in which case it would not matter whether the local corporate governance structure gives preference to shareholder or stakeholder interests. Yet, if environmental and financial performances are not aligned, or if shareholders perceive that to be the case, then preferences should diverge. In fact, historically, there appears to have been a sequence in the logics by which managers and investors perceive of environmental actions - from rejecting environmental efforts as a pure cost, to a more recent trend of pro-actively 
investing in creating environmental capabilities and competitive advantage based on higher production efficiencies or market preference by increasingly environmentally conscious customers (e.g., Russo and Fouts, 1997; King and Lenox, 2001, 2002; Klassen and Whybark, 1999). If environmental efforts are seen as negative for performance then governance systems that provide primacy for shareholders will allow the latter to enforce their preferences via managerial agents to the detriment of stakeholder interests, causing low environmental performance.

Conversely, governance systems that allow for more stakeholder inclusion will afford shareholders with less influence and thus leave managers more exposed to other stakeholder's requests. In fact, accommodating stakeholders including the community or environmental groups who might influence public opinion about a firm's environmental performance (Henriques and Sadorsky, 1999) has been shown to be a conduit to increase environmental performance (Kassinis and Vafeas 2006; Berry and Rondinelli, 1998). Managers, especially when exposed to such pressures through a more stakeholder focused governance system, will then likely attempt to enhance or protect their own or their organization's legitimacy by conforming to the expectations of such stakeholders and thus invest in better environmental performance (Deephouse, 1999; Scott, 1995; Myer and Rowan, 1977; DiMaggio and Powell 1983; Aldrich and Fiol 1994). Overall:

Hypothesis 2: Corporate governance systems that emphasize shareholder protection will be associated with worse environmental performance than those with a lower shareholder protection.

Furthermore, there is likely also a direct effect of institutional logic on environmental performance, as managers and shareholders socialized in a stakeholder system even in the absence of corporate governance mechanisms are likely to act to a 
certain extent more in line with a logic that assigns property a social function. Therefore:

Hypothesis 3: Common law legal origins will be associated with worse environmental performance than civil law legal origins.

Finally, there may also be a moderating effect between institutional logic and the effect of corporate governance systems on environmental firm performance. That is, even if the governance system in a common and civil law country were structurally equivalent in providing primacy for shareholders, it seems reasonable to assume that in a country with a strong stakeholder logic shareholders would still make their decisions with a relatively high regard for the social responsibility of their property. Hence, we expect that a given degree of 'shareholder protection' afforded by local governance structures should lead to decisions at the firm level that are relatively less 'shareholder only' focused as compared to those in common law countries where shareholders are assumed to focus more on their self-interest (e.g., Collins et al. 2012) and thus utilize the governance structures to assert the same. Accordingly, we suggest:

Hypothesis 4: The negative link between corporate governance systems that emphasizes shareholder protection and environmental performance will be stronger in countries with a common law legal origin.

\section{Changing Logics - The Influence of International Environmental}

Agreements. So far we have implicitly treated common and civil law countries as having one dominant logic of either shareholder or stakeholder primacy, respectively. Yet, an increasing body of work focuses on the co-existence of competing logics within organizational fields and the question of how institutional logics emerge and develop over time (e.g., Thornton and Ocasio, 1999; Lounsbury, 2007; Herremans et al., 2009; Nigam and Ocasio, 2010). Accordingly, while the link between legal origins and logics 
seems compelling, it is reasonable to assume that not every actor in, for instance, a common law country is guided by a shareholder primacy logic. Reflecting precisely such a competition between stakeholder and shareholder logics, Herremans et al. (2009: 450) describe how in the Canadian (a common law country) petroleum industry "one population of firms was aligned with increasing pressures from its stakeholders for improved environmental performance, and the other was influenced by local cultural, political, and economic ideals less demanding of environmental actions." Thus, rather than being a deterministic force, legal origins appear to be just one, albeit seemingly important, influence on the institutional logics specific actors follow. Our first set of hypotheses above, like research in the La Porta et al. tradition in general, is therefore based on the assumption that legal origins are strong enough to sway a majority of actors in a country to behave in line with either a belief that property is sacrosanct or that property has a social dimension and decisions thus require integration of stakeholder interests. While average of the findings by prior researchers in the legal origins tradition suggests that this is a very reasonable assumption, the work of Herremans et al. and others cited above, also implies that this balance between competing logics is open to an evolution. In the following we explore some of these dynamics using international environmental agreements.

While the nature of an institutionalized belief is precisely that actors will tend to hold on to their existing belief structure, a number of issues may conceivably influence these structures and thus change the actors' institutional logics. Such factors could include pressure from stakeholders such as regulators (e.g., during the 1990s, the US EPA has added hundreds of Chemicals to the list of substances that need to be disclosed in the 'toxic release inventory' in case of spillage - see EPA TRI program timeline), 
social or media attention like Al Gore’s ‘An Inconvenient Truth’ (Guggenheim, 2006), globalization with multinational companies (MNCs) potentially attempting to 'import' their own institutional logic into host countries with different legal origins (e.g., Tan and Wang, 2011), or an increasing awareness that environmental investments may create competitive advantages and positive financial outcomes (e.g., Russo and Fouts, 1997; King and Lenox, 2001, 2002).

Eberlein and Matten (2009: 247), provide a vivid account of such an evolution of logics, again for the Canadian context, where initially "aligned with the position of many US counterparts at the time, Canadian business associations vigorously campaigned against the ratification of the Kyoto Protocol", yet, after ratification "in late 2005, in a surprising reversal of position, prominent business leaders called for climate change action, through a letter to the Prime Minister wherein the leaders of major Canadian MNCs ... acknowledged corporate responsibilities under the Kyoto Protocol and called for a long-term Canadian strategy to combat climate change.”

The Kyoto Protocol mentioned in this quote is the second of two high profile international environmental agreements that, we suggest, may have put particular pressure on institutional logics to include a stronger stakeholder orientation. Specifically, the United Nations Framework Convention on Climate Change (UNFCCC), an international environmental treaty signed by 154 countries at the 1992 United Nations Conference on Environment and Development (UNCED), was the first environmental event at an international level (Janicke, 2006; Byrne and Glover, 2002). Dubbed the 'Earth Summit', this treaty emphasizes in its non-binding commitments to reduce greenhouse gases that corporations should make changes to their behavior including increased use of renewable energy and the adoption of measures to improve energy efficiency (Janicke, 2006; Byrne and Glover, 2002). Subsequent to 1992, further UNCED 
Conferences took place. In particular, the meeting in Kyoto in 1997 produced a protocol with 141 signatory countries, which set legally binding targets for developed countries to reduce greenhouse emissions over 7 years (from 2005 to 2012) to about 5\% below 1990 levels and introduced the use of market mechanisms such as emission trading schemes (Government of Japan, 2008; Manne and Richels, 1998; Jotzo et al., 1999).

We suggest that by ratifying these accords governments make very visible commitments to stricter environmental targets and thus essentially impose an (environmental) stakeholder centric view on their local firms. By endorsing environmental targets as legitimate, governments, as powerful actors, send a strong signal of the importance of the environment to across stakeholders which in turnleads to isomorphic effects of similar changes in other actors (DiMaggio and Powell, 1983). Furthermore, by changing the ground-rule of what is considered legitimate, these signals contribute to widen perceived legitimacy gaps that will then elicit reactions from various actors ranging from resistance to acquiescence to the new rules as witnessed by Herremans et al. (2009). Besides thus potentially directly affecting the values and beliefs that govern the logics of individual actors, such an endorsement may also act indirectly via an increased sensitization of other actors like consumers to environmental issues. As a result, market opportunities for green products may emerge and thus shift the pure economic logic of environmental actions from a 'cost' to an 'opportunity'. This effect already seems likely to occur with non-binding agreements, but will probably be even stronger if countries commit to binding goals because violation of binding contracts brings punishments both financially and socially through enforcement mechanisms. In particular, regulation (like the reporting and punishment regimen created by the US EPA 
- EPA TRI program timeline) changes the economic logic of environmental investments by imposing costs on non-compliance and exposing socially negative behavior; similarly, market based solutions like the emission trading schemes of the Kyoto protocol will also change the economic payoffs of 'polluting'. Both of these enforcement approaches furthermore publicly emphasize that beliefs and values at the country level favor stakeholder concerns.

Altogether, we suggest that joining international environmental agreements will tend to either directly change the values and beliefs of actors' institutional logics in the direction of more stakeholder inclusion or, even if individual actors maintain a belief of shareholder primacy despite government endorsed alternative values, will change contingencies in such a way that environmental and financial performance of firms become more aligned. As we argued above, if environmental and financial goals are synchronized, there is no de facto difference between a shareholder and stakeholder logic in terms of eventual outcomes. Accordingly, whether by direct change in logics or just an alignment of stakeholder and shareholder logics, we should expect international environmental agreements to affect the governing institutional logics in a focal country such as to enhance the status of stakeholders that are not shareholders.

Yet, the impact of such an enhancement of (environmental) stakeholders' position should vary depending on whether the prevailing institutional logic in a country is already stakeholder focused or not. If it is, then adding some extra governmental pressure due to the international accords will only increment the existing level of stakeholder focus - and, depending on what role environmental stakeholders are already playing in a focal country, that increment may even be negligible. However, in countries that follow a 
more shareholder focused logic the introduction of such a stakeholder focus instead of just adding an 'increment' is likely to cause more friction between existing and newly contending logic and eventually a more pronounced change to the existing logic by now incorporating environmental stakeholders demands. Eberlein and Matten’s (2009) description of the reactions of Canadian (common law) and German (civil law) firms to the ratification of the Kyoto protocol provides some initial validation for our thesis. Specifically, they report - as quoted above - that Canadian firms were initially strongly opposed to environmental efforts, but later on became rather engaged; yet, "contrary to the Canadian business community, German corporations collectively never campaigned against the principle of climate change policy or the landmark Kyoto Protocol. German industry signed on to an early national consensus on the need for mitigation and abatement action." (2009: 249). In line with our theory, in the common law country the Kyoto protocol challenged the existing logic (hence the strong protests), which eventually led to significant changes. In the civil law country, however, the absence of strong reactions suggests that the prevailing institutional logic was simply not challenged much, which also led to less of a change due to the Kyoto protocol as Eberlein and Matten (251) conclude: “Collectively, we have seen how Canadian businesses, after initial resistance, are now constructively engaged in the national debate on a federal regulatory framework ... Similar initiatives in Germany are much less prevalent...” Hence, we suggest::

Hypothesis 5: High profile international legal agreements for environmental protection will have a greater positive effect on environmental performance in countries with a common law legal origin.

Our overall model is depicted in Figure 1.

Insert Figure 1 about here 


\section{Data and Methods}

We test our hypotheses with country-level data on legal origins and corporate governance regimes in the context of $\mathrm{CO}_{2}$ emissions. These particular emissions account for approximately $80 \%$ of the total worldwide emissions of 'greenhouse' gases (Nordhaus, 1991), and are blamed by a large fraction of the research community for global warming and climate change (e.g., Solomon et al. 2009; Cox et al., 2000). While the specific role of carbon emissions remains a contentious issue (Edwards et al. 2001; Solomon et al. 2007; Lafferty, 1999), several high profile International Conferences and Agreements (e.g., the Earth Summit in 1992, Kyoto Protocol in 1997) have revolved around $\mathrm{CO}_{2}$ emissions. Accordingly, we focus on $\mathrm{CO}_{2}$ emissions as a (negative) proxy for environmental performance because these emissions are both, important in their own right, and subject to a number of international agreements that allow us to test our hypotheses regarding external pressures or enforcement mechanism on institutional logics.

Dependent Variable. To construct our negative environmental performance variable we collect country-level data on emission of $\mathrm{CO}_{2}$ emissions measured in metric tons per capita from the World Bank's World Development Indicator. This data is available for the years 1980 to 2011, which defines the maximum sample period for our analysis.

Explanatory Variables. Our primary explanatory variables are measures of the legal origin as well as the structure of corporate governance mechanisms of a given country (the latter are also used as dependent variables in addressing hyp. 1).

Legal Origin is a cross-sectional binary variable (with common-law origin coded 1) for 28 countries that were originally selected by La Porta et al. (1998), who also 
provided this data. Our identification of the Legal Origin variable is based on La Porta et al. (1998) and Head, Mayer and Ries (2010). Given the time-invariant nature of Legal Origin, it forms a constant value throughout our longitudinal data set. Importantly, Legal Origin, as the historical choice or endowment of a given country with a legal system and associated philosophy of property, can safely be considered to be exogenous to our dependent variables, thus avoiding estimation bias due to reverse causality.

The first prediction of our model is that the underlying philosophies that are reflected in different origins of law manifest themselves in an institutionalization of either a shareholder or stakeholder focused logic when it comes to private property. This, in turn, should lead to distinct structures of Corporate Governance across common and civil law legal origins, with the former emphasizing shareholder protection. While we do not have viable data on the intervening construct of shareholder or stakeholder logics, the theoretical model derived from La Porta et al. is quite compelling in terms of suggesting that common law from its very origins supports a shareholder primacy view, while the various civil law systems have developed around some level of treating property as instruments of social policy, which harmonizes with the logic of the stakeholder perspective. Prior studies have come to a similar conclusion (e.g., Collison et al. 2012). We therefore treat the shareholder/stakeholder institutional logic as a latent variable and use the legal origin of a country as an instrument to proxy for this unobserved variable.

To capture the structure of corporate governance in a given country we collected a number of different measures. First, prior studies by La Porta et al. $(1998,2002)$ provided us with cross-sectional measures for the same 28 countries as above, for Shareholder Rights, Creditor Rights and the Wedge between cash flow and control rights. This data 
has been used by prior researchers as well (e.g., Acharya et al., 2011).

The Shareholder Rights index is formed by adding one count each for the presence of six shareholder friendly rules at the country level (see appendix 1 for details) ${ }^{\mathrm{i}}$. This index ranges from zero to five, with higher numbers expressing a stronger protection of shareholders. Creditor Rights is a similarly constructed index aggregating creditor rights, and ranges from zero to four (see appendix 2). The Wedge is defined as the discrepancy between cash flows (i.e., legal ownership) and voting rights. Specifically, voting rights tend to be larger than cash flows (i.e., legal ownership) when an economy is dominated by firms with cross-shareholdings and pyramid structures, because a controlling shareholder of a 'higher level' firm can extend his or her influence (i.e. voting rights) to firms that are positioned further down the pyramidal structure (i.e., owned by the higher level firm) even if that shareholder has no direct ownership of the latter. Higher values of this wedge therefore indicate a higher degree of control by major shareholders, and a higher potential of exploitation of other (minority) shareholders as argued by La Porta et al. (1999) and extended by Claessens et al. (2000).

Second, we obtained time-varying corporate governance data from Aggarwal, Erel, Ferreira, and Matos (2011), which provide an annual country-level governance index for the 2004-2008 period. This variable, G-Index 41, is the degree to which specific firms do or do not meet 41 different governance attributes, expressed as an average per country and year. This average ranges from 0 to $100 \%$, with higher numbers again reflecting a stronger protection of shareholders (see appendix 3). To construct this index, Aggarwal et al. (2011) analysed for 23 industrialized countries a large number of individual firms that accounted for, on average, $80.2 \%$ of the total market capitalisation 
by country in 2008 (all data based on Worldscope). Accordingly, estimations using GIndex 41 are based on a significantly restricted sample in terms of countries and years. Yet, given the global economic significance and the substantial coverage of companies in each country we expect this data to effectively cover the main carbon emitters in the world. Our database also indicates that the shares of these 23 selected countries' CO2 emissions of the total global emissions exceeded 55\% during the 2004-2008 period.

Finally, three binary variables capture the effects of major international events aimed at reducing greenhouse gases including $\mathrm{CO}_{2}$. Earth Summit indicates the 1992 UNFCCC agreement, Kyoto 97 reflects the signing of the Kyoto Protocol in 1997 and Kyoto 05 captures the implementation phase of the Kyoto protocol commencing in 2005. Each binary variable is set to ' 1 ' in the year the respective agreement or implementation commenced and kept at that value for later years, thus covering the 'post Agreement/Implementation start’ periods.

Control variables. Following prior studies, our main control variables include the GDP per capita (GDPPC) and urban population. We were tempted to include more controls. For example, Mazzanti and Zoboli (2008) as well as Klassen and Whybark (1999) demonstrated that technological innovation - to the extent that it helps to increase the material or energy efficiency of production processes and to reduce emission or effluents associated to outputs - is a key factor for achieving a better environmental performance of firms and the economy as a whole. To control for this effect we included a Technology variable calculated as the number of patents applied for by a country's residents in thousands divided by total country population using data from the World Bank's World Development Indicator (not reported). However, inclusion of this 
Technology variable created a multicolliniarity problem with GDP per capita. We had similar problems with controls for Energy Consumption, measured as kg of oil equivalent energy use per 1,000 USD in 2005 constant purchasing power adjusted GDP, and Fossil Fuel energy consumption, expressed as the percentage share of fossil fuel in total energy consumption. As such, and in line with suggestions by Angrist and Pischke (2009) or Amiti and Weinstein (2011), we focus on a more parsimonious model specification. Table 1 provides summary statistics for our variables.

Insert Table 1 about here

Model. To test our hypotheses we estimate a model of the general form:

$$
Y_{i t}=\mathbf{x}_{i t}^{\prime} \boldsymbol{\beta}+\gamma \text { Legal } \text { Origin }_{i}+\theta_{t}+v_{i}+\varepsilon_{i t} .
$$

where $\mathrm{Y}$ is either a measure of corporate governance structure at the country level or our (negative) measure of environmental performance, Legal Origin is a binary variable that is equal to 1 if a country is from a common law legal environment and 0 otherwise, and $\mathrm{X}$ is a vector of other regressors, $\mathbf{x}$, which may include a number of interaction effects between Legal Origin and other variables of interest; $\theta_{t}$ controls for time fixed effects, and $v_{i}$ is a control for country fixed effects.

\section{Results and Discussion}

As discussed above, since we do not observe shareholder or stakeholder logics directly, we address our first hypothesis by regressing our measures of aggregated corporate governance (G-Index 41) and shareholder protection (Shareholder Right), respectively, directly on the binary variable Legal Origin. 
Insert Table 2 about here

Models 1-5 in Table 2 are pooled least square regressions and Model 6 is a Poisson regression that takes the count-data nature of the Shareholder Right variable into account. All estimation results show, in support of our baseline hyp. 1, that a common law legal origin has a strong impact on corporate governance in general as well as strengthened shareholder rights in particular. This finding is not surprising given the strong theoretical foundation that La Porta et al. $(1998,1999,2002)$ provide and that suggests that common law countries have a 'better' corporate governance system that emphasizes the protection of shareholder benefits.

With the results in Table 3 we now address the direct effect of Legal Origin on environmental performance as predicted in hyp. 3. Estimation results in Models 1-3 confirm that a carbon emission increasing effect of a common law shareholder logic is consistently observed even when we control for population and income variables although the statistical significance drops somewhat depending on model specification. The estimated coefficients of the interaction variable between Legal Origin and Population (Legal x POP) and Legal Origin and GDPPC (Legal x GDPPC) are likewise positive, suggesting that the negative environmental impact of a common law shareholder logic is intensified as a country's urban population or income increases.

Insert Table 3 about here

We argue that these results reflect the institutional logic of a common law environment that sees private property as the prerogative of the owner and thus is not conducive to interference by other stakeholders. Accordingly, managers and shareholders decide the environmental 'strategy' of a firm absent much outside interference. The fact 
that this apparently leads to worse pollution seems to reflect a negative sentiment of shareholders that environmental issues are detrimental to profit goals.

Table 4 provides further evidence in support of hyp. 3 as Models 2-5 indicate a strong direct effect of legal origin on emissions even controlling for governance variables. Model 1 in Table 4 furthermore provides evidence regarding hyp. 2, which suggests that a 'better' governance system (i.e., strong shareholder protection) will lead to a worse environmental performance than systems that leave more room for the interests of other stakeholders. In line with this prediction, we find a significant increase in $\mathrm{CO}_{2}$ emissions for higher values of the G-Index 41. For our other corporate governance proxies, however, the results, which are displayed in Table 5, are somewhat mixed. Specifically, while the Shareholder Rights variable in Model 1 of Table 5 is not significant, the additional variables of Creditor Rights and Wedge (for both of which higher values indicate a worsening of shareholder protection for the benefit of other parties) are significant in the expected direction - the more these variables are in the favour of shareholders (i.e., the lower the value of the same), the higher the $\mathrm{CO}_{2}$ emissions.

\section{Insert Table 4 and 5 about here}

While these results provide initial support for the existence of a direct effect of corporate governance on environmental performance, hyp. 4 suggests that a given level of 'good' corporate governance will have different implications depending on the underlying logics of the people interacting with these rules. Table 4 and 5, in fact, provide strong evidence for the existence of such a moderating effect. First, splitting the sample into common law and civil law countries as done in Models 6 and 7 in Table 4 shows that the level of corporate governance has essentially no effect on $\mathrm{CO}_{2}$ emissions 
in a civil law country, while the earlier observed negative effect on $\mathrm{CO}_{2}$ of 'good' corporate governance on environmental performance seems to come exclusively from common law countries.

The same pattern can be observed across Model 4 in Table 5. The estimated coefficient of the interaction variable between Shareholder Rights and Legal Origin is positive and statistically significant at conventional levels. This finding suggests a significant $\mathrm{CO}_{2}$ increasing effect in common law countries compared to civil law countries in the presence of strong shareholder protection; similarly, an absence of creditor rights (and thus a strengthening of shareholders) would significantly increase emissions in common-law countries vis-à-vis civil law countries; for the Wedge, however, we find counterintuitive results that weaken the support for our thesis somewhat. Overall, however, these results indicate that in countries with a predominantly stakeholder focused logic governance issues do not seem to matter - presumably, environmental issues are taken into consideration whether or not governance systems are strong or weak. In more shareholder focused common law countries, however, strong rights provided to shareholders are apparently used to block environmental initiatives. We further investigate this link by forming interactions between Legal Origin and the top and bottom quartiles of G-Index 41 (G-Index 75 th $\times$ Legal Origin, G-Index ${ }_{25 t h} \times$ Legal Origin). As models 3-5 in table 4 show, while very 'good' governance has no further impact in a common law country, 'bad' governance structures actually lead to reduced emissions thus, in common law countries, bad governance seems to be good for the environment! Overall, we see these results as strong support for hyp. 4, and interpret them as suggesting that it is not so much the actual governance mechanisms (e.g., board 
independence, incentive pay etc. - e.g., Kock et al. 2012) that shape social outcomes like environmental performance, but 'how' these mechanisms are employed by actors with different logics. This further implies that the governance structure that emerges in a common law system to protect property rights is not per se 'bad' for social issues as, for example, Collison et al. (2012) suggest, but that in combination with the institutional logic of focusing primarily on shareholder interests otherwise equivalent structures turn into socially bad outcomes.

Our last set of hypotheses take this idea further by suggesting that if external events bring different logics closer together, outcomes will become more similar again. Table 6 provides results for such events, the Earth Summit and the Kyoto Protocol. Looking at the direct effect of the voluntary commitments of the Earth Summit or the binding action plans of the Kyoto Protocol, we find essentially no significant direct $\mathrm{CO}_{2}$ reducing effect. This finding is consistent with much public resignation related to the alleged ineffectiveness of these international agreements (Purvis, 2004; Fisher et al., 2004). However, the interactions of the two variables proxying for the initial agreements (Earth Summit and Kyoto 97) with Legal Origins are both negative and highly significant, indicating that the emissions reduction effect of these agreements is much stronger in countries with a common law legal origin. This provides strong support for our hyp. 5 and the associated idea that these agreements and the regulatory reactions or changes to the public discourse and perception of environmental issues changes the shareholder logic in common law countries to either become, on the margin, substantively similar to a stakeholder logic, or at least affect the contingencies in such a way that a shareholder logic would yield similar effects as a stakeholder logic. 
Insert Table 6 about here

The implementation proxy Kyoto 05, as well as the interaction of the same with legal origins, while showing signs in the right direction, are not significant. However, the fact that the mere start of the implementation phase of the Kyoto agreement does not seem to create an additional impetus of change to the institutional logic of common law countries and, furthermore, that the interactions between Legal Origins and the three Agreement/Implementation variables show a clearly decreasing magnitude of coefficients from the earliest (Earth Summit) to the latest (Kyoto 05), provides further support for the overall idea that we are seeing a process of convergence whereby at least for the area of environmental management shareholder logic gives way for a more stakeholder focused approach even in common law countries. The effect of further and further external changes of the same nature might then lead to decreasing marginal effects.

\section{Limitations}

As every study, our paper has some limitations that should be taken into account when interpreting our results. Due to data and space constraints our analysis was squarely focused on the country level. While this approach corresponds to the focus on legal origins and prior work in this tradition (e.g., La Porta et al. 1997, 2000; Collison et al., 2012), it obscures the heterogeneity of institutional logics at the level of individual actors. Likewise, factors such as the presence of MNCs that may 'import' different institutional logics are not accounted for in our model. Yet, as Tan and Wang (2011) suggest, the behavior of MNCs in a host country may range from insistence on their own existing logics to symbolic or substantive acceptance of the logic prevailing in the host country. For our current study we therefore assume that the effects of MNCs will tend to cancel 
out and blend in with the variation in individual logics that should be present in any country, and that legal origins are strong enough to sway the balance of institutional logics in a given country in a predictable direction. However, in addressing our final hypothesis we have already explicitly addressed the idea that this balance may evolve due to external events. In any case we believe that a promising avenue for future work would be to integrate firm level and other more fine-grained data in order to refine our understanding of how heterogeneous institutional logics co-evolve.

Similarly, we have suggested that international environmental agreements might act in two rather different ways on institutional logics - by changing the nature of a shareholder logic itself, or by simply altering contingencies such that the same shareholder logic still leads to stakeholder friendly outcomes. While our results show indeed a convergence process, we were not able to disentangle which type of change actually happened, i.e., did shareholder-focused owners and managers become more stakeholder oriented? Or did they simply realize that what is best for the environment also is best for themselves? This, we believe, is an important challenge for future studies.

\section{Conclusions}

We have developed a theoretical model of 'environmental governance' that extends prior approaches by a crucial element - the origins of law and the associated institutional logics within a given country. We suggest that these legal origins, or more precisely, the underlying philosophies regarding freedom, property and commonality, have a strong shaping influence on the explicit corporate governance systems, which in turn affect the propensity of firms to incorporate the demands of various stakeholder groups. In the context of environmental performance, we argue and show that the effects of these 
underlying logics occur directly, are mediated via governance systems, and, perhaps most importantly, act to moderate the impact of these governance systems.

While the connection between legal origins and governance systems has been made in prior literature (Daniel et al., 2012), we have provided a model of how these legal origins and distinct logics will eventually impact the environmental performance of firms, thereby providing a missing link to the environmental governance literature as well as contributing to the delineation of the legal origins model by exploring a distinct social outcome that complements recent work by Collison et al. (2012).

Utilizing aggregated data at the country level provided strong support for our theses in the context of $\mathrm{CO}_{2}$ emissions as an important environmental outcome variable. Overall, our results indicate that common law countries, due to their intrinsically more shareholder-focused logic, face significantly higher levels of emissions - a situation that is ironically even exacerbated when governance is 'good' in a traditional sense (i.e., providing strong protection for shareholders). Accordingly, when analysing the effect of governance systems on stakeholder related issues such as environmental performance the nature of the institutional logics in a given country environment ought to be taken into account to avoid confounding the results. Additionally, these institutional logics are likely to develop over time, suggesting that empirical studies that only look at one country environment in a specific time frame may come to conclusions about the effect of variables such as corporate governance mechanisms that, in fact, are more reflective of a particular state of development of the underlying logics than of the focal variable at hand. For example, Kock et al. (2012) report for the US context (a classical common law country) that 'good' governance is associated with high environmental performance. 
However, in their analysis they focused on data for the years 1998 and 2000, which reflects a time period where the underlying institutional logic in the US had already been affected by the Earth Summit and the Kyoto protocol, and the logic of pro-active environmental management (e.g., King and Lenox, 2001) had already proliferated to some extent. Likewise, the US EPA had started in the 1990s to include many more chemicals on their watchlist for the disclosure of environmental spills (EPA TRI program timeline). These effects, as we propose in this paper, have likely already shifted a formerly purely shareholder centric view towards more accommodation of stakeholder perspectives as well as changed the perceived payoffs of environmental strategies for shareholders, thereby altering the effects of governance mechanisms. In fact, one key finding of our study is that it is not so much the set of actual governance mechanisms (e.g., board compensation, pays structure etc. - e.g., Kock et al. 2012) that shape social outcomes like environmental performance, but 'how' these mechanisms are employed by actors with different logics. Future research could profitably further develop our understanding of these temporal structures of changing institutional logics and governance mechanisms, while regulators and other decision makers should consider the effects documented here when interpreting and acting upon empirical studies linking governance structures and environmental outcomes.

The basic idea that a shareholder focused logic leads to a lower emphasis on the environment, and a more stakeholder friendly logic creates better environmental outcomes seems actually pretty straightforward. In this sense, our first set of hypotheses and results provides further support for Collison et al. (2012) who have shown with a range of indicators of societal well-being that the superiority La Porta et al. claim for the 
common law system extends only or primarily to economic but not to social outcomes.

Yet, at least in the context of environmental performance, social outcomes do not necessarily have to suffer in a common law system. In fact, we started our theoretical discussion with an analysis of why, exactly, a shareholder focused logic and corporate governance systems that give primacy to the same would lead to worse environmental outcomes - in a nutshell, when shareholder see environmental efforts as a cost whose benefits others enjoy and simultaneously do not have specific values or beliefs that compel them to benefit stakeholders anyhow! Thus, the institutional logic that determines decision-making by firms in common law countries is dominated by shareholders, which are negatively predisposed to 'wasting' their money on the environment. This assessment, however, prompted us to investigate how that 'logic' might actually change in such a way that protection of the environment is seen in a more positive light. This could happen if either the institutional logic itself changes to include benefitting stakeholders as a moral objective and/or if the cost/benefits equation of environmental investments changes, for example if environmental activities are increasingly seen as a potential competitive advantage - as appears to be the case for many environmentally pro-active firms in recent times (e,g. King and Lenox, 2002) - or if environmental underperformance becomes a costly liability due to governmental or market reactions.

Our results also add to the debate on the effectiveness or futility of international environmental agreements. While widespread disappointment with the lacking support of the Kyoto Protocol (e.g., non-ratification by the USA - Manne and Richels, 2001; Lahrach et al., 2004) and the more recent near-failure of the Doha Conference (Keating, 2012; see also the non-significant main effects of the agreement dummies in our table 6) 
express doubts as to the ability of nations to overcome the classical 'tragedy of the commons' problematic of worldwide pollution increases, our results provide a glimmer of hope for the future of international efforts to stem against the climate change tide by showing that these agreements do, in fact, have an impact, particularly in the countries that seem least prone to environmental protection to begin with. Our study reveals that we cannot simply judge the results of these vast, multilateral agreements by looking at the average 'return' across all countries. Rather, we need to take into account the different contingencies, i.e., the institutional logics prevailing in each country. Countries that are already quite socialized in a stakeholder focus may, in fact, not need these agreements - if their governments commit to a scheme such as the Kyoto Protocol, the resulting signals and enforcement actions may simply not add anything to what is already being done. To quote Eberlein and Matten (2009: 251) again, "the German case points to the fact that with strong civil society pressures towards greener business practices there are strong incentives for voluntary business initiatives towards ethical behaviour." Thus, stakeholder focused countries are not 'low hanging' fruits from the perspective of scoring visible successes with such agreements as their constituencies are likely to have formed a strong stakeholder focused business ethics already, potentially even leading to an environmental performance ahead of regulation. Rather, an effect might come from countries where due to a shareholder focused logic the discrepancy between current situation and new mandates by the government is largest. Governments endorsing and promoting new, stakeholder oriented values essentially prompt isomorphic tendencies (DiMaggio and Powell, 1983) as well as create legitimacy gaps for businesses (see also discussion in Herremans et al., 2009), and by proposing new regulation or market based mechanisms like emission trading change the current logic of how to attain profitability. While these changes are likely to elicit 
contention and strife (just as in the prior evidence for Canada quoted above), over time firms may acquiesce to a new logic - or simply find that their old logic of shareholder profit maximization, given the new contingencies, is best served by also accommodating stakeholders - not for morale, but pragmatic reasons. Organizers of international agreements should therefore focus on engaging governments of countries with the largest gap between current and desired logics and to help these governments in leveraging the instruments discussed above to effect substantial changes to institutional logics or change the contingencies of business to align shareholder and stakeholder interests.

While our study adds the importance of the endowment with a specific institutional logic due to countries' legal origins to recent efforts at understanding interactions between businesses, governments, regulation and ethics (Eberlein and Matten, 2009), competing logics of populations of organizations within industries (Herremans et al., 2009), and the emerging literature on environmental governance (e.g., Kock et al, 2012, Berrone et al, 2010), we stop short of identifying to what extent international environmental agreements indeed are able to change the nature of specific actors logics or simply affect the contingencies around the same. Accordingly, from a social ethics perspective, the key question that is yet to be answered is what specific levers are available to sway actors from a shareholder to a stakeholder logic, or, failing that, how a shareholder focused actor can be persuaded to still act with regard to stakeholder interests.

\section{References}

Acharya, V. V., Amihud, Y., \& Litov, L. 2011. Creditor rights and corporate risk-taking, Journal of Financial Economics, 102: 150-165.

Aggarwal, R., Erel, I., Ferreira, M., \& Matos, P. 2011. Does governance travel around the world? 
Evidence from institutional investors, Journal of Financial Economics,100:154-181.

Aldrich, H. E., \& Fiol, C. M. 1994. Fools rush in? The institutional context of industry creation. Academy of Management Review, 19: 645-670.

Amiti, M., \& Weinstein, D. E. 2011. Exports and Financial Shocks, Quarterly Journal of Economics, 126: 1841-1877.

Angrist, J. D. \& Pischke, J-S. 2009. Mostly Harmless Econometrics, Princeton University Press.

Aragón-Correa, J. A., Matías-Reche, F., \& Senise-Barrio, M. E. 2004. Managerial discretion and corporate commitment to the natural environment. Journal of Business Research, 57: 964-975.

Bebchuk, L., Cohen, A., \& Ferrell, A. 2009. What matters in corporate governance? Review of Financial Studies 22, 783-827.

Berrone, P., Cruz, C., Gomez-Mejia, L. R., \& Larraza-Kintana, M. 2010. Socioemotional wealth and corporate responses to institutional pressures: Do family-controlled firms pollute less? Administrative Science Quarterly, 55: 82-113.

Berry, M.A. \& Rondinelli, D.A. 1998. Proactive corporate environmental management: A new industrial revolution. Academy of Management Executive, 12:38-50.

Buzzelli, D. T. 1991. Time to structure an environmental policy strategy. Journal of Business Strategy, 12(2): 17-20.

Byrne, J., \& Glover, L., 2002. A common Future or Towards a Future Commons: Globalisation and Sustainable Development since UNCED, International Review for Environmental Strategies, 3: 5-25.

Claessens, S., Djankov, S., \& Lang, L.H.P., 2000. The separation of ownership and control in East Asian Corporations, Journal of Financial Economics, 58: 81-112.

Collison, D., Cross, S., Ferguson, J., Power, D., \& Stevenson, L., 2012. Legal Determinants of External Finance Revisited: The Inverse Relationship Between Investor Protection and Societal Well-Being, Journal of Business Ethics, 108: 393-410

Cox, P. M., Betts, R. A., Jones, C. D., Spall, S. A., \& Totterdell, I. J. (2000). Acceleration of global warming due to carbon-cycle feedbacks in a coupled climate model, Nature, 408, 184-187.

Daniel, S. J., Cieslewicz, J. K., \& Pourjalali, H., 2012, The impact of national economic culture and country-level institutional environment on corporate governance practices, Management International Review, 52, 365-394.

Deephouse, D. L. 1999. To be different, or to be the same? It's a question (and theory) of strategic balance. Strategic Management Journal, 20: 147-166.

DiMaggio, P. J., \& Powell, W. W. 1983. The iron cage revisited: Institutional isomorphism and collective rationality in organizational fields. American Sociological Review, 48: 147-160.

Eberlein, B., Matten, D. 2009. Business Responses to Climate Change Regulation in Canada and Germany: Lessons for MNCs from emerging economies. Journal of Business Ethics, 86:241-255

Edwards, P. G. \& Miller, C. A. 2001. Changing the atmosphere: expert knowledge and environmental governance. Cambridge, Mass: MIT Press.

EPA TRI Program timeline. Accessible under: http://www2.epa.gov/toxics-release-inventory-triprogram/tri-program-timeline-0

Fisher, B. S., Woffenden, K., Matysek, A., Ford, M., \& Tulpule, V. 2004. Alternative to the Kyoto Protocol: A new climate policy framework?, International Review for 
Environmental Strategies, 5:179-197.

Freeman, R. E., 1984, Strategic Management: a stakeholder approach, Cambridge: Cambridge University Press.

Freeman, R. E., 1999, Divergent stakeholder theory, Academy of Management Review, 24: 233236.

Friedland, R., \& Alford, R. 1991. Bringing society back in: Symbols, practices, and institutional contradictions. W. W. Powell, P. DiMaggio, eds. The New Institutionalism in Organizational Analysis. University of Chicago Press, Chicago, 232-263.

Friedman, M., 1970, The Social Responsibility of Business Is to Increase Its Profits, New York Times Magazine, September 13, 1970.

Gompers, P., Ishii, J., \& Metrick, A., 2003, Corporate governance and equity prices, Quarterly Journal of Economics, 116: 229-259.

Government of Japan. 2008, Kyoto Protocol Target Achievement Plan, Tokyo, Japan: Ministry of the Environment, Government of Japan, pp. 81-82, 28 March (http://www.env.go.jp/en/earth/cc/kptap.pdf)

Greeno, J. L. \& Robinson, S. N. 1992. Rethinking corporate environmental management, Columbia Journal of World Business, 27: 222-232.

Guggenheim, D. 2006. An Inconvenient Truth: A Global Warning: Paramount.

Hayek, F. A. 1960. The Constitution of Liberty, Chicago: University of Chicago Press.

Head, K., Mayer, T., \& Ries, J. 2010. "The erosion of colonial trade linkages after independence”, Journal of International Economics, 81:1-14.

Henriques, I., \& Sadorsky, P. 1999. The relationship between environmental commitment and managerial perceptions of stakeholder importance. Academy of Management Journal, 42:87-99.

Herremans, I. M., Herschovis, M. S., \& Bertels, S. 2009. Leaders and Laggards: The Influence of Competing Logics on Corporate Environmental Action. Journal of Business Ethics, 89: 449-472

Hill, C. W. L., \& Jones, T. M. 1992. Stakeholder-Agency Theory, Journal of Management Studies 29, 131-154.

Hiller, D., Pindado, J., de Queiroz, V., \& de la Torre, C. 2011. The impact of country-level corporate governance on research and development, Journal of International Business Studies, 42:76-98.

Janicke, M. 2006. The 'Rio Model' of Environmental Governance - a General Evaluation, http://ssrn.com/abstract=926968.

Johnson, R.A. \& Greening, D.W. 1999. The effects of corporate governance and institutional ownership types on corporate social performance. Academy of Management Journal, 42, 564-576.

Jotzo, F., Polidano, C., Brown, S., \& Stuart, R. 1999. Global environmental measures and the Kyoto Protocol: An evaluation of international emissions trading, Paper presented at Symposium on Pacific Energy Cooperation - SPEC '99, Dai-ichi Hotel, Tokyo, 16-17 February.

Kassinis, G. \& Vafeas, N. 2006. Stakeholder pressures and environmental performance, Academy of Management Journal, 49: 145-59.

Keating, D. 2012. Disappointment in Doha, EuropeanVoice.Com (http://www.europeanvoice.com/article/imported/disappointment-in-doha/75964.aspx, extracted on 14 January 2013). 
Klassen, R. D. \& Whybark, D. 1999. The impact of environmental technologies on manufacturing performance, Academy of Management Journal, 42: 599-615.

King, A. A., \& Lenox, M. J. 2000. Industry self-regulation without sanction: The chemical industry's responsible care program, Academy of Management Journal, 43:698-716.

King, A. A., \& Lenox, M. J. 2001. Does It Really Pay to Be Green? An Empirical Study of Firm Environmental and Financial Performance, Journal of Industrial Ecology, 5:105-116.

King, A. A., \& Lenox, M. J. 2002. Exploring the locus of profitable pollution reduction. Management Science, 48(2): 289-299.

Kock, C. J., Santalo, J. \& Diestre, L. 2012. Corporate governance and the environment: What types of governance creates greener companies? Journal of Management Studies, 49:492-514.

Lafferty, W. 1999. The pursuit of sustainable development-concepts, policies, and arenas. International Political Science Review 20:123-28.

Lahrach, R., Tensorer, J.L., \& Merlin, V. 2004. Who benefits from the US withdrawl of the Kyoto protocol? Memeo, CREM, University of Caen, France.

La Porta, R., Lopez-de-Silanes, F., Shleifer, A., Vishny, R.,1997. Legal determinants of external finance, Journal of Finance 52, 1131-1150.

La Porta, R., Lopez-de-Silanes, F., Shleifer, A., \& Vishny, R. 1998. Law and finance, Journal of Political Economy 106, 1113-1150.

La Porta, R., Lopez-de-Silanes, F., Shleifer, A., \& Vishny, R. 2000. Agency problems and dividend policies around the world, Journal of Finance 55, 1-33.

La Porta, R., Lopez-de-Silanes, F., Shleifer, A., \& Vishny, R. 2002. Investor protection and corporate valuation, Journal of Finance 57, 1147-70.

La Porta, R., Lopez-de-Silanes, \& F., Shleifer, A. 2008. The economic consequences of Legal Origins, Journal of Economic Literature, 46(2), 285-332.

Lounsbury, M. 2007. 'A Tale of Two Cities: Competing logics and practice variation in the professionalizing of Mutual Funds', Academy of Management Journal, 50, 289-307.

Luo, X., Chung, C-N. \& Sobczak, M. 2009. How do corporate governance model differences affect foreign direct investment in emerging economies? Journal of International Business Studies, 40:444-467.

Manne, A., \& Richels, R. 1998. The Kyoto Protocol: a cost-effective strategy for meeting environmental objectives? Paper presented at the Energy Modeling Forum Meeting, Snowmass, Colorado, August 19-11.

Manne, A.S., \& Richels, R.G. 2001. US rejection of the Kyoto Protocol: the impact on compliance costs and CO2 emissions, mimeo, Stanford University.

Mazzanti, M., \& Zoboli, R. 2008. Environmental innovations, SME strategies and policy induced effects: Evidence for a district-based local system in Nothern Italy, ICFAI Journal of Environmental Economics, 6:7-34.

Meyer, J., \& Rowan, B. 1977. Institutional organizations: Formal structure as myth and ceremony. American Journal of Sociology, 83: 340-363.

Newman, J. G., \& Breeden, K. M. 1992. Managing in the environmental era: Lessons from environmental leaders. Columbia Journal of World Business, 27: 210-221.

Nigam, A., Ocasio, W. 2010. Event attention, environmental sensemaking, and change in institutional logics: An inductive analysis of the effects of public attention to Clinton's health care reform initiative. Organization Science, 21(4):823-841.

Nordhaus, W. 1991. To slow or not to slow: The economics of the greenhouse effect, Economic 
Journal, 101:920-937.

Purvis, N. 2004. The perspective of the United States on Climate Change and the Kyoto Protocol, International Review for Environmental Strategies, 5:169-177.

Porter, M. E., \& van der Linde, G. 1995. Green and competitive: Ending the stalemate. Harvard BusinessReview, 73(5): 120-134.

Russo, M. V. \& Fouts, P. A. 1997. A resource-based perspective on corporate environmental performance and profitability. Academy of Management Journal, 40(3): 534-559.

Scott, W. R. 1995. Institutions and Organizations. Thousand Oaks, CA: Sage.

Sharma, S. \& Henriques, I. 2005. Stakeholder influences on sustainability practices in the Canadian forest products industry. Strategic Management Journal, 26: 159-180.

Solomon S, Plattner G-K, Knutti R, \& Friedlingstein P. 2009. Irreversible climate change due to carbon dioxide emissions. Proceedings of the National Academy Sciences, 106: 17041709.

Solomon, S., Qin, D., Manning, M., Chen, Z., Marquis, M., Averyt, K. B., Tignor, M., \& Miller, H. L., ed., 2007. Climate Change 2007: The Physical Science Basis, Contribution of Working Group I to the Fourth Assessment Report of the Intergovernmental Panel on Climate Change, Cambridge University Press

Soshimori, M. 1995. Whose company is it? The concept of the corporation in Japan and the West, Long Range Planning, 28(4): 33-44.

Tan, J., \& Wang, L. 2011. MNC strategic responses to ethical pressure: An institutional logic perspective. Journal of Business Ethics, 98: 373-390

Thornton. P. H., Ocasio, W. 1999. Institutional logics and the historical contingency of power in organizations: Executive Succession in the Higher Education Publishing Industry, 19581990. American Journal of Sociology, 105: 801-843

Thornton. P. H., Ocasio, W. 2008. Institutional logics. R. Greenwood, C. Oliver, K. Sahlin, R. Suddaby, eds. Handbook of Organizational Institutionalism. Sage Publications, London, 99-129.

Walls, J. L., Berrone, P. \& Phan, P. H. 2012. Corporate Governance and environmental performance: Is there really a link. Strategic Management Journal, 33: 885-913.

World Bank, 2012. World Development Indicators, World Bank. Washington D.C. 


\section{APPENDIX}

\section{Appendix 1 - Components of Shareholder Rights Index,La et al. (1998)}

The Shareholder Rights index is formed by adding one count each for the presence of the following six shareholder friendly rules at the country level:(i) the country allows shareholders to mail their proxy vote to the firm, (ii) shareholders are not required to deposit their shares prior to the general shareholder's meeting, (iii) cumulative voting or proportional representation of minorities of the board of directors is allowed, (iv) an oppressed minorities mechanism is in place, (v) the minimum percentage of share capital that entitles a shareholder to call for an extraordinary shareholder's meeting is less than or equal to 10 percent (the sample median) or (vi) shareholders have pre-emptive rights that can be waived only by a shareholders' vote.

\section{Appendix 2 - Components of Creditor Rights Index,La Porta et al. (1998)}

Creditor Rights is the sum of the following four indexes, which is provided by La Porta et al. (1998): (1) No automatic stay - equals one if a business reorganization procedure does not impose an automatic stay on the assets of the firm upon filing the reorganization petition, allowing creditors to seize their collateral after the reorganization petition is approved. It equals zero if such restriction does exist in the law; (2) Reorganization - equals one if the reorganization procedure imposes restrictions, such as creditors' consent or minimum dividend for a debtor to be able to file for reorganization. It equals zero for countries without such restriction; (3) Secured debt first - equals one if secured creditors are ranked first in the distribution of proceeds of the disposition of the assets of a bankrupt firm; Equals zero if non-secured creditors, such as the government and workers, are given absolute priority; (4) No management stay - Equals one if an official appointed by the court, or by the creditors, is responsible for the operation of the business during reorganization, and management does not retain administration of its property pending the resolution of the reorganization.

\section{Appendix 3 - Components of G-Index 41, Aggarwal et al. (2011)}

The G-Index 41 consists of 41 governance attributes that are organized into four subcategories: (i) board (ii) audit (iii) anti-takeover provisions, and (iv) compensation and ownership. There are 24 governance attributes for (i) boards, including the existence of a governance committee and whether the board is controlled to more than 50 percent by independent directors, 3 attributes for (ii) audit, including whether the audit committee is composed solely of independent outsiders, 6 attributes for (iii) anti-takeover provisions, including whether the company either has no poison pill or a pill that is shareholder approved, and 8 attributes for (iv) compensation and ownership, including whether directors receive all or a portion of their fees in stock. G-Index 41, as an additive index, assigns a value of one to each of the 41 governance attributes if the company meets minimally acceptable guidelines on that attribute, and zero otherwise. Then, index is expressed as a percentage. If a firm satisfies all 41 governance attributes, then its G-Index 41 will be equal to 100 percent.

The following numbers of firms per country went into the computation of G-Index 41 for each year: Australia (102), Austria (18), Belgium (25), Canada (166), Denmark (22), Finland (29), France (82), Germany (86), Greece (41), Hong Kong (57), Ireland (16), Italy (65), Japan (571), Netherlands (42), New Zealand (17), Norway(22), Portugal (14), Singapore (58), Spain (52), Sweden (44), Switzerland (59), U.K. (45) and U.S. (4921). The average share of market capitalisation of these selected companies in each country is 80.2 percent of the Worldscope total market capitalisation by country in 2008. 
Table 1: Summary statistics

\begin{tabular}{|c|c|c|c|c|c|c|c|c|}
\hline Variable & $\mathbf{N}$ & mean & sd & P50 & $\min$ & $\max$ & Definition & Sources \\
\hline \multicolumn{9}{|c|}{ A. Carbon emissions } \\
\hline \multicolumn{9}{|l|}{$\mathrm{CO} 2$ /person } \\
\hline & 6134 & 4.59 & 6.32 & 2.22 & 0.00 & 68.6 & $\begin{array}{l}\text { CO2 emissions, metric tons per } \\
\text { capita }\end{array}$ & $\begin{array}{l}\text { WDI, World Bank } \\
\text { (2012) }\end{array}$ \\
\hline $\begin{array}{l}\text { (2)common law } \\
\text { country }\end{array}$ & 1783 & 4.85 & 6.95 & 1.29 & 0.00 & 37.9 & & \\
\hline & 4351 & 4.48 & 6.04 & 2.58 & 0.01 & 68.6 & & \\
\hline \multicolumn{9}{|c|}{ (3) civil law country } \\
\hline \multicolumn{9}{|l|}{$\begin{array}{l}\text { B. Country } \\
\text { characteristics }\end{array}$} \\
\hline Urban population & 6530 & 0.74 & 2.73 & 0.03 & 0.01 & 34.8 & Person in millions & $\begin{array}{l}\text { WDI, World Bank } \\
\text { (2012) }\end{array}$ \\
\hline GDP/person & 6530 & 7142 & 11181 & 2090 & 57.8 & $1.08 \times 10^{5}$ & GDP per capita & $\begin{array}{l}\text { WDI, World Bank } \\
\text { (2012) }\end{array}$ \\
\hline \multicolumn{9}{|l|}{ C. Corporate } \\
\hline (1) Legal Origin & 742 & 0.31 & 0.46 & 0 & 0 & 1 & $\begin{array}{l}1 \text { if a country is common law legal } \\
\text { origin, } 0 \text { otherwise }\end{array}$ & $\begin{array}{l}\text { La Porta et al. } \\
(1998,2002), \\
\text { Acharya et al. } \\
\text { (2011). }\end{array}$ \\
\hline (2) G-Index 41 & 115 & 45.0 & 8.45 & 44.9 & 27.3 & 72.8 & $\begin{array}{l}\text { Corporate governance index using } 41 \\
\text { firm-level components. It ranges from } \\
0 \text { to } 100 \text {. }\end{array}$ & $\begin{array}{l}\text { Aggarwal, Erel, } \\
\text { Ferreira, and } \\
\text { Matos (2011) }\end{array}$ \\
\hline $\begin{array}{l}\text { (3) Shareholder } \\
\text { right }\end{array}$ & 736 & 2.87 & 1.42 & 3 & 0 & 5 & $\begin{array}{l}\text { Index to indicate the level of } \\
\text { shareholder right protection. It ranges } \\
\text { from } 0 \text { to } 5 .\end{array}$ & $\begin{array}{l}\text { La Porta et al. } \\
(2002)\end{array}$ \\
\hline $\begin{array}{l}\text { (4) Creditor } \\
\text { right }\end{array}$ & 736 & 1.91 & 1.02 & 2 & 0 & 4 & $\begin{array}{l}\text { Index to indicate the level of creditor } \\
\text { right protection. It ranges from } 0 \text { to } 4 \text {. }\end{array}$ & $\begin{array}{l}\text { La Porta et al. } \\
\text { (2002) }\end{array}$ \\
\hline (5) wedge & 144 & 0.1 & 0.07 & 0.09 & 0.01 & 0.37 & $\begin{array}{l}\text { Difference between the average } \\
\text { control rights and cash-flow rights in a } \\
\text { country }\end{array}$ & $\begin{array}{l}\text { La Porta et al. } \\
\text { (2002) }\end{array}$ \\
\hline \multicolumn{9}{|c|}{ D. International Env. } \\
\hline \multicolumn{9}{|l|}{ Agreement } \\
\hline (1) Earth Summit & 6530 & 0.60 & 0.49 & 1 & 0 & 1 & $\begin{array}{l}1 \text { if year belongs to } 1993 \text { and beyond, } \\
\text { and } 0 \text { otherwise. }\end{array}$ & $\begin{array}{l}\text { UNFCC web home } \\
\text { page }\end{array}$ \\
\hline (2) kyoto97 & 6530 & 0.44 & 0.5 & 0 & 0 & 1 & $\begin{array}{l}1 \text { if year belongs to } 1998 \text { and beyond, } \\
\text { and } 0 \text { otherwise: agreement }\end{array}$ & $\begin{array}{l}\text { Kyoto Protocol } \\
\text { web home page }\end{array}$ \\
\hline (3) kyoto05 & 6530 & 0.19 & 0.39 & 0 & 0 & 1 & $\begin{array}{l}1 \text { if year belongs to } 2006 \text { and beyond, } \\
\text { and } 0 \text { otherwise: implementation }\end{array}$ & $\begin{array}{l}\text { Kyoto Protocol } \\
\text { web home page }\end{array}$ \\
\hline
\end{tabular}


Table 2: Effect of common law on corporate governance and shareholder right

\begin{tabular}{|c|c|c|c|c|c|c|}
\hline & \multicolumn{5}{|l|}{ Pooled OLS } & \multirow{2}{*}{$\begin{array}{l}\text { Poisson } \\
\text { regression } \\
(6) \\
\text { Shareholder } \\
\text { Rights }\end{array}$} \\
\hline & $\begin{array}{l}\text { (1) } \\
\text { G-Index } 41\end{array}$ & $\begin{array}{l}\text { (2) } \\
\text { G-Index } 41\end{array}$ & $\begin{array}{l}\text { (3) } \\
\text { G-Index } 41\end{array}$ & $\begin{array}{l}\text { (4) } \\
\text { Shareholder } \\
\text { Rights }\end{array}$ & $\begin{array}{l}\text { (5) } \\
\text { Shareholder } \\
\text { Rights }\end{array}$ & \\
\hline Legal Origin & $\begin{array}{l}8.958 * * * \\
{[5.77]}\end{array}$ & $\begin{array}{l}8.958^{* * *} \\
{[6.08]}\end{array}$ & $\begin{array}{l}15.620^{* * *} \\
{[24.62]}\end{array}$ & $\begin{array}{l}1.214^{* * *} \\
{[10.32]}\end{array}$ & $\begin{array}{l}1.214^{* * *} \\
{[10.10]}\end{array}$ & $\begin{array}{l}0.511 * * * \\
{\left[6.14 \times 10^{5}\right]}\end{array}$ \\
\hline $\begin{array}{l}\text { Year-effect } \\
\text { Country- } \\
\text { effect }\end{array}$ & No & Yes & Yes & No & Yes & Yes \\
\hline Intercept & $\begin{array}{l}41.927^{* * *} \\
{[55.56]}\end{array}$ & $\begin{array}{l}42.888^{* * *} \\
{[27.24]}\end{array}$ & $\begin{array}{l}44.310^{* * *} \\
{[48.10]}\end{array}$ & $\begin{array}{l}2.500^{* * *} \\
{[48.18]}\end{array}$ & $\begin{array}{l}2.500^{* * *} \\
{[8.93]}\end{array}$ & $\begin{array}{l}1.099 * * * \\
{\left[2.99 \times 10^{5}\right]}\end{array}$ \\
\hline $\mathrm{N}$ & 115 & 115 & 110 & 736 & 736 & 736 \\
\hline Adjusted $R^{2}$ & 0.251 & 0.352 & 0.884 & 0.153 & 0.116 & n.a. \\
\hline Pseudo_R $R^{2}$ & n.a. & n.a. & n.a. & n.a. & n.a. & 0.262 \\
\hline
\end{tabular}

${ }^{*}, * *, * * *$ refers to 10,5 and 1 percent significance level respectively. Figures in parentheses are heteroscedasticity-robust t-values.

G-Index 41 is a firm-level corporate governance index aggregated to country level, while Shareholder Rights is an index variable indicating the level of shareholder protection, ranging from 0 to 5 . 
Table 3: Estimation of the Effect of Legal Origin on $\mathrm{CO}_{2}$ Emissions

\begin{tabular}{|c|c|c|c|c|c|c|}
\hline & (1) & $(2)$ & (3) & (4) & (5) & (6) \\
\hline & $\mathrm{CO}_{2}$ & $\mathrm{CO}_{2}$ & $\mathrm{CO}_{2}$ & $\mathrm{CO}_{2}$ & $\mathrm{CO}_{2}$ & $\mathrm{CO}_{2}$ \\
\hline \multirow[t]{2}{*}{ Legal origin } & $0.365 * *$ & $0.405 * *$ & $0.231^{*}$ & 0.137 & -0.203 & $-0.259 *$ \\
\hline & {$[2.00]$} & {$[2.12]$} & [1.69] & {$[0.94]$} & {$[1.32]$} & {$[1.71]$} \\
\hline \multirow[t]{2}{*}{ Legal X POP } & & & & $0.672 * * *$ & $0.569 * * *$ & $0.519 * *$ \\
\hline & & & & [3.31] & {$[2.66]$} & {$[2.50]$} \\
\hline \multirow[t]{2}{*}{ Legal X GDPPC } & & & & & $0.052^{*}$ & $0.057^{*}$ \\
\hline & & & & & [1.69] & [1.87] \\
\hline \multirow[t]{2}{*}{ Population } & & $0.043^{* * *}$ & $0.040 * * *$ & $0.036 * * *$ & $0.037^{* * *}$ & $0.030 * * *$ \\
\hline & & {$[2.78]$} & [5.58] & {$[5.20]$} & {$[5.17]$} & [3.78] \\
\hline \multirow[t]{2}{*}{ GDPPC } & & & $0.427 * * *$ & $0.426 * * *$ & $0.406 * * *$ & $0.408 * * *$ \\
\hline & & & [32.63] & [32.33] & {$[28.20]$} & [28.02] \\
\hline \multirow[t]{2}{*}{ year } & & & & & -0.026 & $-0.045^{* *}$ \\
\hline & & & & & [1.39] & {$[2.32]$} \\
\hline \multirow[t]{2}{*}{ Country $\mathrm{X}$ year } & & & & & & $0.000 * * *$ \\
\hline & & & & & & [2.89] \\
\hline Year-effect & Yes & Yes & Yes & Yes & Yes & Yes \\
\hline \multirow[t]{2}{*}{ _cons } & $4.484 * * *$ & $4.438 * * *$ & $2.137 * * *$ & $2.155^{* * *}$ & 52.865 & $91.312^{* *}$ \\
\hline & [48.96] & [45.14] & [5.73] & {$[5.77]$} & [1.44] & {$[2.37]$} \\
\hline $\mathrm{N}$ & 6134 & 6134 & 5671 & 5671 & 5671 & 5671 \\
\hline Adjusted $\mathrm{R}^{2}$ & 0.001 & 0.001 & 0.478 & 0.479 & 0.481 & 0.482 \\
\hline
\end{tabular}

Note: Population and GDPPC respectively refer to urban population in million and GDP per capita in 1000 USD. ${ }^{*},{ }^{* *},{ }^{* *}$ refers to 10,5 and 1 per cent significance level respectively. Figures in parentheses are heteroscedasticity-robust t-values. 
Table 4: Effects of Time-Varying Country-Level Corporate Governance on $\mathrm{CO}_{2}$

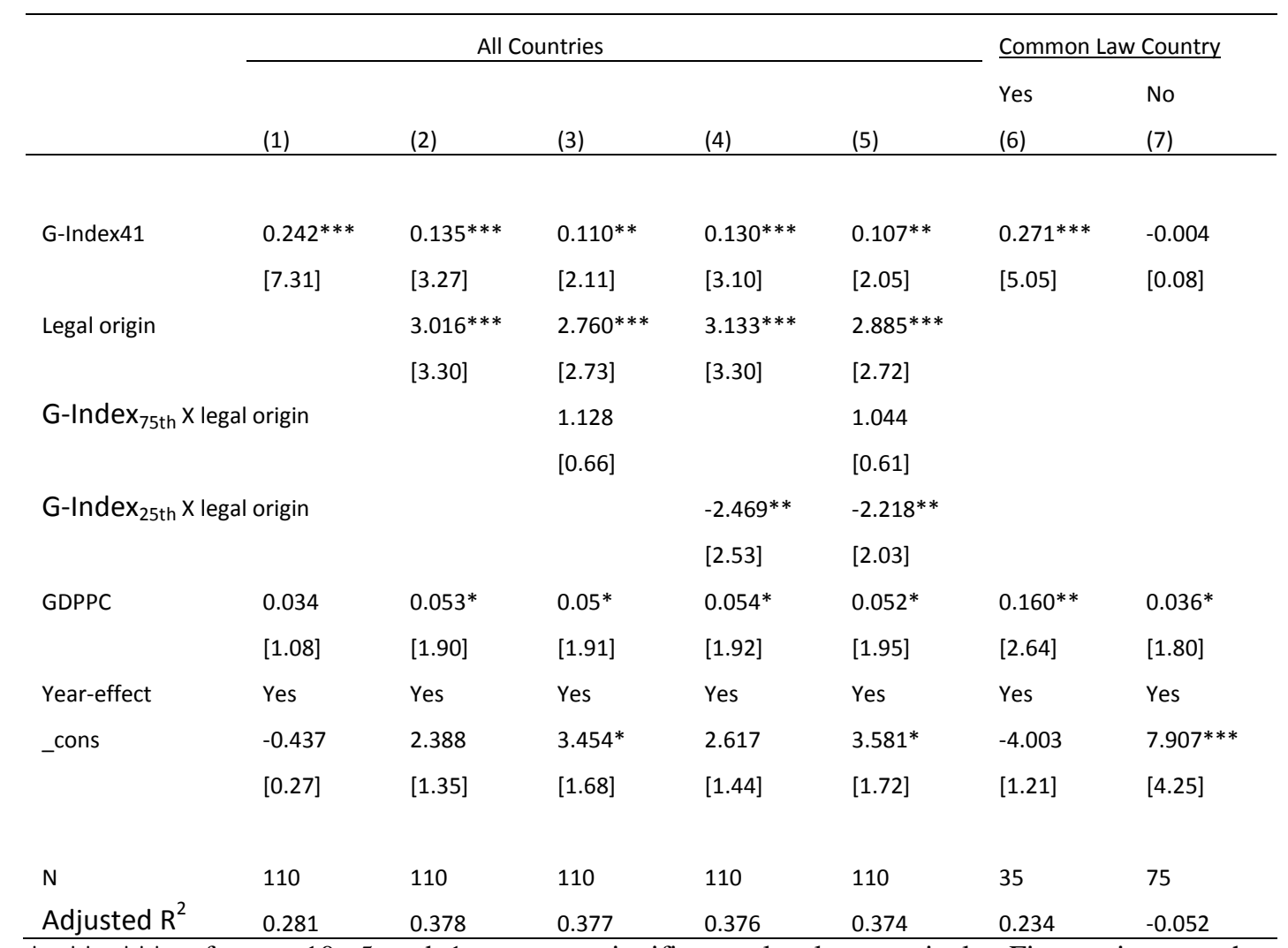

$*, * *, * * *$ refers to 10,5 and 1 per cent significance level respectively. Figures in parentheses are heteroscedasticity-robust t-values. 
Table 5: Effects of Shareholder and Stakeholder Rights and Legal Origin on $\mathrm{CO}_{2}$

\begin{tabular}{|c|c|c|c|c|}
\hline & (1) & $(2)$ & (3) & (4) \\
\hline \multirow[t]{2}{*}{ Shareholder Rights } & 0.002 & & & -0.006 \\
\hline & {$[0.39]$} & & & [1.17] \\
\hline \multirow[t]{2}{*}{ Creditor Rights } & & $-0.012^{* *}$ & & -0.002 \\
\hline & & {$[1.90]$} & & {$[0.23]$} \\
\hline \multirow[t]{2}{*}{ Wedge } & & & $-0.238 * *$ & $-0.172^{* *}$ \\
\hline & & & {$[2.52]$} & {$[2.00]$} \\
\hline \multirow[t]{2}{*}{ Legal Origin } & & & & 0.046 \\
\hline & & & & [1.05] \\
\hline \multirow[t]{2}{*}{ Shareholder right X Legal Origin } & & & & $0.020 * *$ \\
\hline & & & & {$[2.28]$} \\
\hline \multirow[t]{2}{*}{ Creditor right X Legal Origin } & & & & $-0.132 * * *$ \\
\hline & & & & {$[7.44]$} \\
\hline \multirow[t]{2}{*}{ Wedge $X$ Legal Origin } & & & & $4.208 * * *$ \\
\hline & & & & {$[7.73]$} \\
\hline \multirow[t]{2}{*}{ GDPPC } & $0.112^{* * *}$ & $0.118^{* * *}$ & $0.054^{* * *}$ & $0.046^{* * *}$ \\
\hline & {$[7.32]$} & {$[8.46]$} & [7.21] & {$[5.74]$} \\
\hline Year-effect & Yes & Yes & Yes & Yes \\
\hline \multirow[t]{2}{*}{ _cons } & $0.525^{* * *}$ & $1.013^{* * *}$ & $0.350 * * *$ & $0.253^{* * *}$ \\
\hline & {$[12.70]$} & {$[12.23]$} & [14.28] & [7.95] \\
\hline $\mathrm{N}$ & 656 & 656 & 138 & 138 \\
\hline Adjusted $R^{2}$ & 0.548 & 0.55 & 0.19 & 0.616 \\
\hline
\end{tabular}


Table 6: Pooled Estimation of Effect of the International Environmental Agreements on $\mathrm{CO}_{2}$ Emissions

\begin{tabular}{|c|c|c|c|c|}
\hline & (1) & (3) & (2) & (4) \\
\hline & $\mathrm{CO}_{2}$ & $\mathrm{CO}_{2}$ & $\mathrm{CO}_{2}$ & $\mathrm{CO}_{2}$ \\
\hline \multirow[t]{2}{*}{ Legal Origin } & $0.693 * * *$ & $0.503^{* * *}$ & $0.257^{* *}$ & $0.502 * * *$ \\
\hline & {$[3.56]$} & [3.06] & [1.95] & {$[3.05]$} \\
\hline \multirow[t]{2}{*}{ Earth Summit } & 0.561 & & & 0.301 \\
\hline & {$[1.47]$} & & & {$[0.81]$} \\
\hline \multirow[t]{2}{*}{ Legal Origin $\times$ Earth Summit } & $-0.858 * * *$ & & & \\
\hline & [3.15] & & & \\
\hline \multirow[t]{2}{*}{ Kyoto 97} & & -0.478 & & -0.176 \\
\hline & & {$[0.94]$} & & {$[0.40]$} \\
\hline \multirow[t]{2}{*}{ Legal Origin $\times$ Kyoto 97} & & $-0.771 * * *$ & & $-0.770 * * *$ \\
\hline & & {$[2.67]$} & & {$[2.66]$} \\
\hline \multirow[t]{2}{*}{ Kyoto 05} & & & -0.392 & \\
\hline & & & {$[0.75]$} & \\
\hline \multirow[t]{2}{*}{ Legal Origin $\times$ Kyoto 05} & & & -0.609 & \\
\hline & & & [1.17] & \\
\hline \multirow[t]{2}{*}{ GDPPC } & $0.427 * * *$ & $0.427 * * *$ & $0.427 * * *$ & $0.426 * * *$ \\
\hline & {$[32.78]$} & [32.79] & [32.70] & [32.78] \\
\hline Year -effects & Yes & Yes & Yes & Yes \\
\hline \multirow[t]{2}{*}{ Intercept } & $1.400 * * *$ & $2.075 * * *$ & $2.155^{* * *}$ & $1.463^{* * *}$ \\
\hline & {$[5.05]$} & {$[5.61]$} & {$[5.78]$} & {$[5.28]$} \\
\hline $\mathrm{N}$ & 5671 & 5671 & 5671 & 5671 \\
\hline Adjusted $\mathrm{R}^{2}$ & 0.478 & 0.479 & 0.479 & 0.478 \\
\hline
\end{tabular}

$*, * *, * * *$ refers to 10,5 and 1 percent significance level respectively. Figures in parentheses are heteroscedasticity-robust t-values. 
Figure 1: Theoretical Model

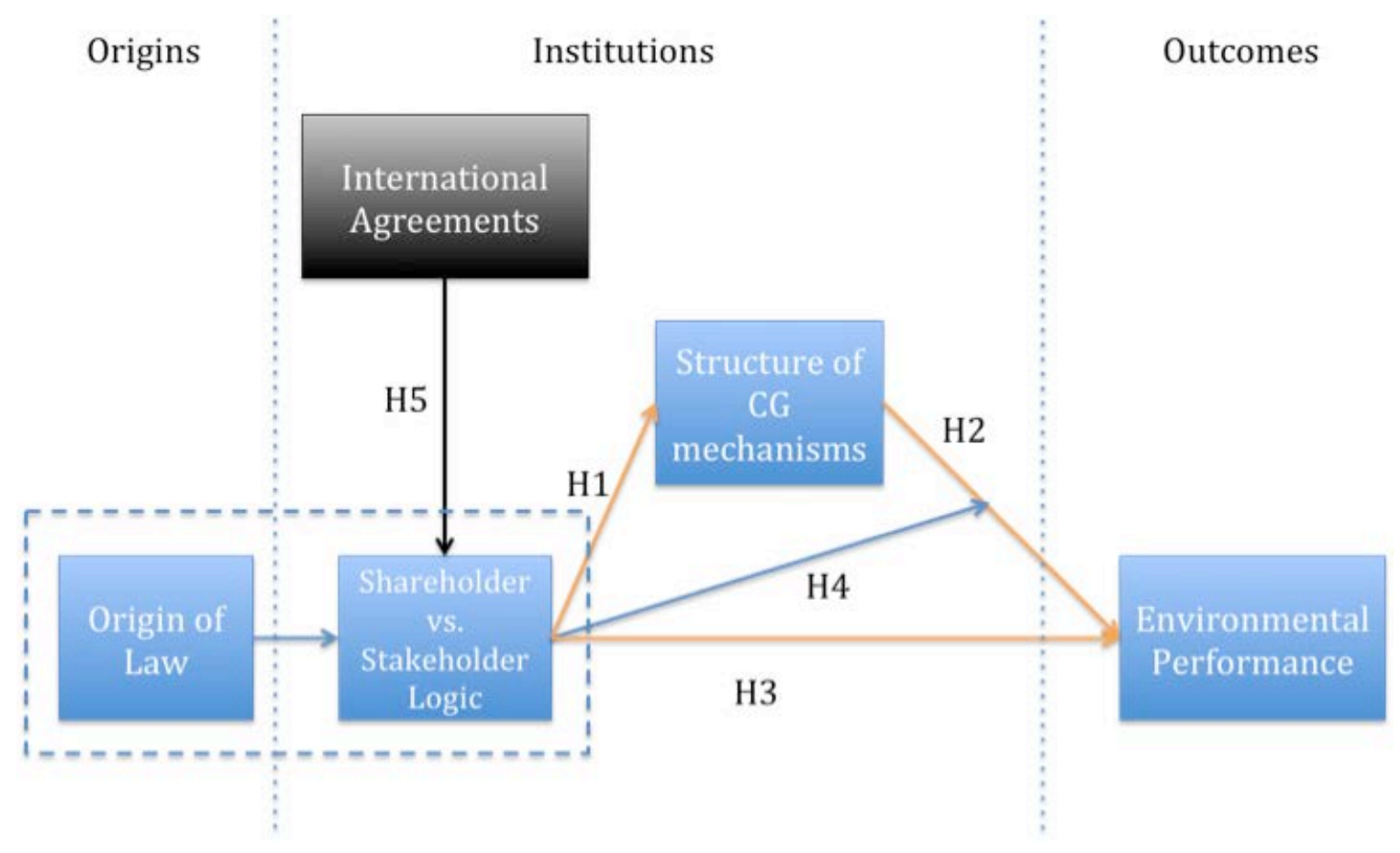

${ }^{\mathrm{i}}$ Additive indices are widely used by empirical researchers (e.g., Gompers et al., 2003; Bebchuk et al., 2009). 